特集記 事

\title{
ダイズ突然変異体リソースの整備と新規アリルの開発に関する研究
}

穴井豊昭

佐賀大学農学部, 佐賀市, $=840-8502$

\section{Development of soybean mutant resources and identification of novel mutant alleles}

Toyoaki Anai

Faculty of Agriculture, Saga University, Saga 840-8502, Japan

キーワード

ダイズ，突然変異体，TILLING，遺伝子機能，育種素材

\section{はじめに}

ダイズ [Glycine $\max$ L. (Merr.)] は，世界で年間 34,180 万トン（SoyStats 2019）生産される重要なマメ科作物で ある。その種子には，乾燥重量の約 $40 \%$ のタンパク質と 約 $20 \%$ の油脂が含まれて扣り, 栄養価が高く, 今後も増 加し続ける世界人口を支える重要な戦略作物の一つであ る. そのため, 世界的な人口増加や温暖化等にも対応す る必要があり, 高温障害や湿害, 病害虫の発生といった 困難な課題を克服し，生産性の更なる向上や安定化を実 現することが求められている。我が国に拈いて，ダイズ は伝統的な食品である豆腐や納豆, 味増等の原料として 古くから利用されて扣り，我々の食文化とは切り離せな いものとなっている. 一方, 世界的にみると, ダイズの 用途は，搾油用が最も多く，次いで飼料用，食用となっ て扣り，油脂成分の改良も極めて重要な課題である。 た，近年では，イソフラボンやサポニンといった機能性 成分にも注目が集まっており, 食と健康といった観点か ら，これらの分子を標的とした成分育種にも期待が寄せ られている。加えて，タンパク質を豊富に含むという特 徵を生かして, 食肉の代替となる植物肉としての利用も 急増している，この様に多様化する用途に対応した新品 種の育成を推進するためには，望まれる形質に関与する 遺伝子の特定と機能解析を進めるとともに，既存の遺伝 資源の利用はもとより，突然变異誘発やゲノム編集等の 技術を用いて種内变異を拡大し，育種に利用可能な新規 アリルの開発を加速する必要があると考えられる.

そこで, 我々は, 従来の形質ベースの順遺伝学的スク

2020 年 9 月 25 日受領 日本育種学会賞受賞 (第 142 号) 2020 年 11 月 11 日 J-STAGE 早期公開

Correspondence: anai@cc.saga-u.ac.jp
リーニングと塩基配列ベースの逆遺伝学的なスクリーニ ングの双方に対応可能なダイズの突然変異体リソースの 整備に取り組み（Anai 2012, Tsuda et al. 2015)，これらの リソースを活用した有用遺伝子の機能解析ならびに新規 アリルの開発を進めてきた。ここでは, 我々が本研究に 取り組むに至った経緯と, 開発したダイズ突然変異体り ソースおよび得られた変異体についての概要を紹介し, これらの変異体を活用したダイズ育種の可能性と, 我々 が特に注力してきた油脂成分改良の現状について子報告 する。

\section{1. 脂肪酸含量変異体の単離と原因遺伝子の同定 から変異体リソースの整備へ}

ダイズ油脂は，全世界で生産される植物油脂の約 $28 \%$ を占めて扣り，パーム油脂に次いで第 2 位となっている. また, 比較的安価で生産も安定していることから, 食用 油や調理油のほか, マーガリンやショートニング等の原 料油脂としても重要な役割を果たしている。ささらに，近 年では, 石油の代替品として, インクや機械油, バイオ ディーゼル等の化成品原料にも利用が増加している。し かしながら，一般的なダイズ油脂はパーム油やキャノ一 ラ油と比較すると空気酸化し易いことから，常温で長期 保存した場合や高温調理時の酸化と, それに伴らオフフ レーバーの発生が問題とされてきた。この様な油脂の酸 化の原因は，ダイズ油脂中に豊富に含まれているリノ一 ル酸や $\alpha$-リノレン酸といった多価不飽和脂肪酸であり, これらの多価不飽和脂肪酸を減少させるためには, ダイ ズの脂肪酸代謝経路を遺伝的に改良することが有効であ ると考えられる.

高木らは，約 2 万系統の「Bay」に由来するX-線照射 後代を調査し，ダイズ油脂に含まれる主要な 5 種類の脂 
肪酸組成が変化した変異体を単離して，これらの遺伝様 式について報告している（高木・ラーマン 2002）。しか しながら，筆者がこの課題に取り組み始めた 1990 年代後 半, これらの変異体が保持する変異アリルについての情 報は，汇とんど明らかになっていなかった。そのため， ダイズの脂肪酸合成経路の解明と育種のための変異アリ 几の分子マーカー化を目指して，これらの原因遺伝子の 同定に取り組むことにした。 また，当時は，ダイズはも とより，イネやシロイヌナズナですら全ゲノム塩基配列 が決定されていなかったため, 他の一部の植物種で報告 されていた脂肪酸合成酵素遺伝子をプローブとして, cDNA ライブラリーやゲノミックライブラリーから, 類 似した塩基配列を持つ遺伝子ファミリーを単離し, 個々 の遺伝子の発現パターンや組換えタンパク質の酵素活性 を指標として，それぞれの変異アリルとその酵素活性と の対応を調査した。

その結果, 以前の研究で得られていた脂肪酸含量変異 体の大部分について，原因となる变異アリルの同定に成 功したが (Anai et al. 2003, Anai et al. 2005, Anai et al. 2008, Anai et al. 2012, Hoshino et al. 2011, Hoshino et al. 2020), ダイズゲノム中には, 登熟中の種子で発現し, 正 常な活性を持つ酵素をコードするにもかかわらず，これ らに対応する変異体が報告されていない遺伝子も少なか らず存在することが明らかになった。 これは，個々の脂 肪酸の合成には，機能的に重複する複数の遺伝子が関与 している上，脂肪酸組成が気温などの栽培環境による影 響を受けやすいことから，表現型に基づく変異アリルの スクリーニングでは, 効果の大きい変異アリルが優先的 に得られた結果であると考兄られた。そこで，まだ得ら れていない変異アリルを, 迅速かつ確実に単離する方法
を模索する中で，従来からの表現型に基づいたスクリー ニングの限界を再認識し, 逆遺伝学的なスクリーニング 系の必要性を痛感するに至った。

\section{2. 突然変異体リソースと逆遺伝学的スクリーニ ング系の整備}

広範囲の作物種に抒いて, 祖先種からの進化の過程で 異種間交雑やゲノムの倍加を経験しており, ダイズでも 2 回のゲノム倍加を経て栽培種が成立して和り，ほとん ぞの遺伝子について機能的重複が認められる。 この様に ゲノム重複が生じている作物種においては, 単一の遺伝 子に変異を生じた個体であっても, 表現型の変化が少な かったり，ほとんど変化が観察されなかったりする場合 も多く, 表現型から変異の有無を判別することが困難な ことも多い，これに対して，逆遺伝学的な変異アリルの スクリーニングは, 表現型の変化が少なく判別が難しい 遺伝子を標的とした場合に特に有効である。また，逆遺 伝学的なスクリーニングを行ら際には, 変異密度が高い 突然変異体集団の作成と簡便で正確な変異アリル検出法 の確立が，この成否に大きな影響を与えることになる。

そこで, 演者は, TILLING (targeting induced local lesions in genomes）法（McCallum et al. 2000）を含を複数の逆遺 伝学的なスクリーニング法を比較・検討し，比較的容易 に変異アリルを検出可能な改变 TILLING 法を開発した. また，こ机と並行して，二世代にわたって EMSを反復処 理することにより，生理的な障害を最小限に抑えつつ， 極めて高密度に変異を導入した突然变異体集団が作成で きることも明らかにした（図 1）(Anai 2012）。その後, この技術を使用して, 我が国で最も生産量の多い「フク

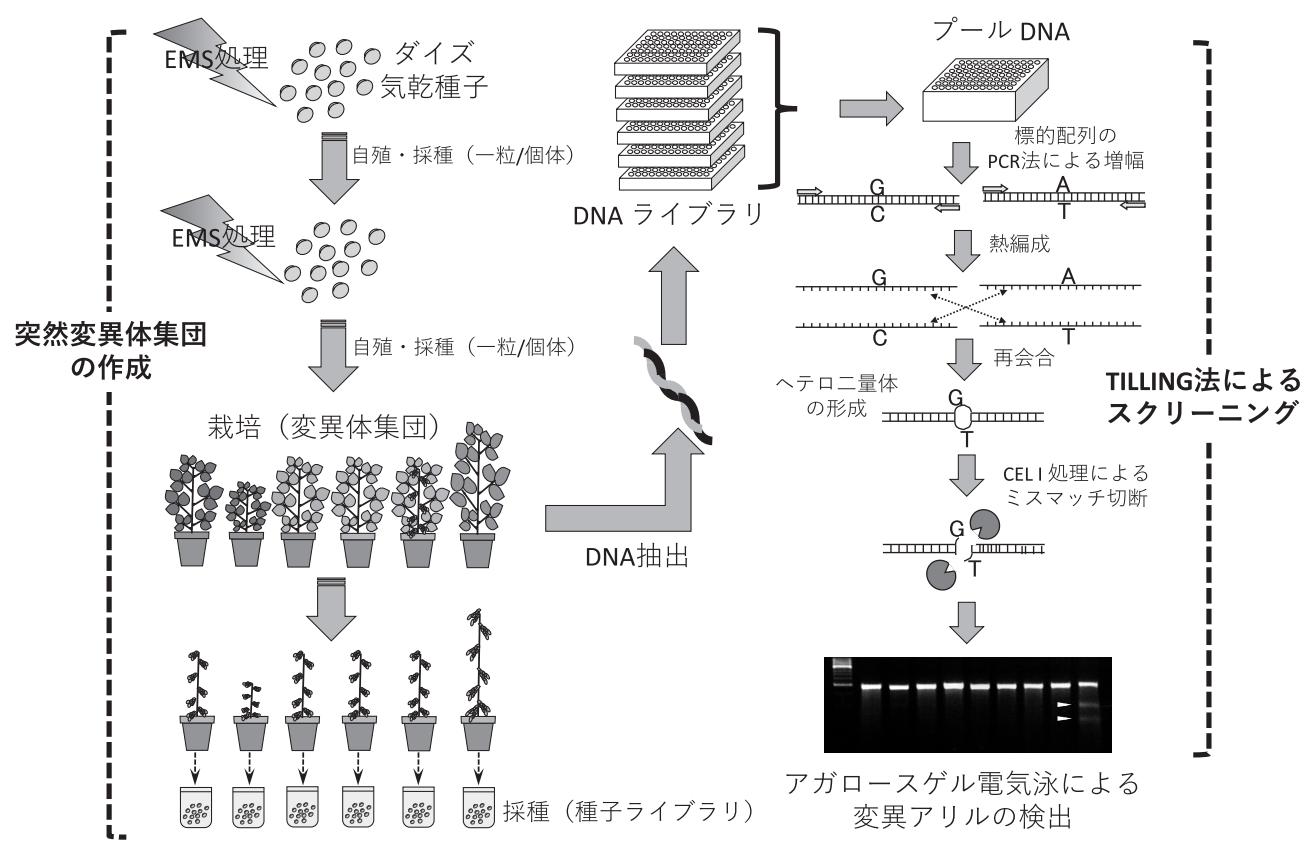

図 1. ダイズの高密度突然变異集団の作成と TILLING 法による検出 (Anai 2012 より改変). 
表 1. 突然変異リソースを利用して改良されたダイズの脂肪酸組成

\begin{tabular}{|c|c|c|c|c|c|c|}
\hline \multirow{2}{*}{ 品種/系統名 } & \multicolumn{5}{|c|}{ 脂肪酸組成（\%） } & \multirow{2}{*}{ 備考 } \\
\hline & パルミチン酸 & ステアリン酸 & オレイン酸 & リノール酸 & $\alpha$-リノレン酸 & \\
\hline フクユタカ & 11.2 & 2.5 & 22.0 & 56.2 & 8.1 & 基準品種 \\
\hline 佐大 HO1 号 & 7.6 & 2.5 & 82.0 & 4.2 & 3.7 & 二重変異体 \\
\hline 高オレイン酸・低リノレン酸系統 & 7.7 & 2.2 & 80.6 & 8.4 & 1.0 & 五重変異体 \\
\hline
\end{tabular}

ユタカ」や，生産量が第 2 位の「エンレイ」（Tsuda et al. 2015)，耐病性等に特徴を持つ「Peking」(Ishibashi et al. 2019）などを親品種とした変異体集団の作成にも取り組 み，これらの突然変異体リソースの一部は，我が国のダ イズ研究コミュニティ内に抒いて, 多様な新規形質に関 わる変異アリルのスクリーニングに活用されている.

一方で，ポジショナルクローニングによって見出され た新規遺伝子の機能解析を目的として, 候補遺伝子上に 生じた変異アリルを単離するといった利用も可能となり, 開花期関連遺伝子の単離などにも貢献することが出来た (Watanabe et al. 2009, Watanabe et al. 2011, Xia et al. 2012)。その後, 変異アリルのスクリーニング法について も TILLING 法に加兄て, 電気泳動が不要な HRM（high resolution melt）法，スクリーニング時点でアミノ酸配列 の情報も得られるアンプリコンシークエンス法など新た な選択肢も増え，より利用しやすい環境が整っている。

また，これらの高い変異密度を持つ突然変異体リッー スは，表現型に基づいたスクリーニングに执いても有用 であることから，サポニン (Yano et al. 2017, Yano et al. 2018, Takagi et al. 2018, Krishnamurthy et al. 2019) やイy フラボン（Sarkar et al. 2020）などの二次代謝変異体をは じめ，小葉の形を制御する遺伝子（Sayama et al. 2017） やカドミウムの蓄積に関与する遺伝子 (Hirata et al. 2019)，除草剂抵抗性に関与寸る遺伝子（Kato et al. 2020) の機能解析, メタボローム解析による一次代謝物を対象 とした変異体の単離とその変異アリルのカタログ化など にも活用されている。これら一連の研究で得られた突然 変異体には, 脂肪酸, イソフラボン, アミノ酸和よび糖 などの代謝が変化したものが含まれて打り，これらは， 今後のダイズ種子成分育種を進める上で貴重な遺伝資源 となると考光られる。

\section{3. 新たな脂肪酸突然変異体の単離とダイズ油脂 改良の現状}

一般的なダイズ油脂の脂肪酸組成をみると，酸化安定 性が低いりノール酸や $\alpha$-リノレン酸といった多価不飽和 脂肪酸が，総脂肪酸の 6 割以上を占めている。これらの 多価不飽和脂肪酸の含量は, それぞれ，小胞体型 $\omega-6$ 脂 肪酸不飽和化酵素をコードする GmFAD2 遺伝子ファミ リーと小胞体型 $\omega$-3 脂肪酸不飽和化酵素をコードする GmFAD3 遺伝子ファミリーの働きによって制御されてい
る。また，GmFAD2 遺伝子ファミリーでは, GmFAD2-1a と GmFAD2-1bの 2 遺伝子が (Anai et al. 2005), GmFAD3 遺伝子ファミリーでは, GmFAD3-1a, GmFAD3-1b 㧊よび GmFAD3-2a の 3 遺伝子が（Anai et al. 2008）登熟中の種 子で特異的に発現し, ダイズ油脂の脂肪酸組成に影響を 与えていることが明らになった。 このうち, GmFAD2-1a, GmFAD3-1 $a$ および GmFAD3-1b 遺伝子の変異アリルにつ いては，表現型に基づいたスクリーニングで既に得られ ていたが，GmFAD2-1b とGmFAD3-2a 遺伝子の変異アリ ルについての報告は全くなかったため, 前述の「フクユ タカ」由来の変異体リソースに対して，TILLING 法を用 いた逆遺伝学的スクリーニングを行ったところ，それぞ れの遺伝子に対応する変異アリルが得られた。更に, GmFAD2-1 $1 a$ と GmFAD2-1b 遺伝子の二重変異系統を作出 したところ，オレイン酸が総脂肪酸の $80 \%$ 以上にまで増 加して扮り, 多価不飽和脂肪酸は $10 \%$ 以下に減少するこ とが明らかになった（Hoshino et al. 2010）。また， GmFAD3-1a，GmFAD3-1b 抢よび GmFAD3-2a 遺伝子の三 重変異系統では， $\alpha$-リノレン酸含量が総脂肪酸の $1 \%$ 台 にまで減少することも明らかになった（Hoshino et al. 2014).

その後, これらのらち GmFAD2-1 $a$ と GmFAD2-1b 遺伝 子の二重変異を導入したダイズ新品種「佐大 $\mathrm{HO} 1$ 号」を 育成して，2018 年に品種登録の申請を行なった。この 「佐大 HO1 号」から抽出した油脂について, CDM 試験に より酸化安定性を評価したところ，基準品種の「フクユ タカ」と比較して約 5 倍も高い酸化安定性を持つことが 示された，加えて，豆乳加工時等にリポキシゲナーゼが リノール酸を分解することで発生し，青臭みの原因とな るn-へキサナールについても，基質となるリノール酸の 含量が極めて低いことから，浮とんど発生が認められな いことも明らかになっている。また，高オレイン酸型の 二重変異系統と低 $\alpha$ - リノレン酸型の三重変異系統の交配 後代から, 約 $80 \%$ のオレイン酸かつ約 $1 \%$ のリノレン酸 含量となる五重変異系統（高オレイン酸・低リノレン酸 系統）の選抜にも成功して和り（表 1)，酸化安定性が極 めて高い油脂を生産するダイズ品種の育成が可能である ことが示された.

\section{4. おわりに}

筆者が本研究に着手した頃を思い返してみると，モデ 
ル植物であるシロイヌナズナやイネを材料とした分子遺 伝学研究は随分と先を走っており，ダイズを材料とした 研究には, 技術的にも解決すべき課題が山積していた. しかし，その後のゲノム解析技術の進歩やゲノム編集技 術の出現により，ダイズを研究材料とした場合の技術的 な障壁もずいぶんと解消されたのではないかと感じてい る. 近年では, 世界規模での食料問題や地球温暖化問題 を解決する糸口となる可能性を秘めた，植物肉の原料と いった新規用途に適したダイズの需要増加も見込まれる ことから，多様化する需要にマッチした品種の育成も望 まれて沶り，その育種素材となる変異体の重要性は益々 高まるのではないだろらか.

最後に, 本研究で取り組んだダイズ突然変異体リソー スについても, 今後, 多くのダイズ研究者や育種家に活 用され，新たな遺伝子の発見や新たな品種の育成につな がることを願ってやまない.

\section{謝 辞}

本研究は, 多くの共同研究者, 研究協力者のサポート を受けて実施されたものであり, 関係の皆様には, この 場を借りて，心より感謝の意を表したい.

特に, ダイズの突然変異体研究へと導いていただいた 佐賀大学の高木㭌名誉教授, ならびに共に研究に汗を流 してくれた植物遺伝育種学研究室のメンバーに, 厚くお 礼を申し上げる。

\section{引用文献}

Anai, T., M. Koga, M. Tanaka, T. Kinoshita, S.M. Raman and Y. Takagi (2003) Plant Cell Rep. 21: 988-992.

Anai, T., T. Yamada, T. Kinoshita, S.M. Rahman and Y. Takagi (2005) Plant Sci. 106: 1615-1623.

Anai, T., T. Yamada, R. Hideshima, T. Kinoshita, S.M. Rahman and Y. Takagi (2008) Breed. Sci. 58: 447-452.

Anai, T. (2012) Breed. Sci. 61: 462-467.

Anai, T., T. Hoshino, N. Imai and Y. Takagi (2012) Breed. Sci. 61: 631-638.

Hirata, K., K. Takagi, T. Yamada, T. Sayama, T. Anai, A. Kikuchi and M. Ishimoto (2019) Breed. Sci. 69: 345-351.

Hoshino, T., Y. Takagi and T. Anai (2010) Breed. Sci. 60: 419-425.
Hoshino, T., N. Kawashita, Y. Takagi and T. Anai (2011) Plant Breed. 130: $544-550$.

Hoshino, T., S. Watanabe, Y. Takagi and T. Anai (2014) Breed. Sci. 64: 371-377.

Hoshino, T., N. Iijima, M. Hata, A. Watanabe, T. Kawakami and T. Anai (2020) Plant Gene 21: 100207.

Ishibashi, K., M. Saruta, T. Shimizu, M. Shu, T. Anai, K. Komatsu, N. Yamada, Y. Katayose, M. Ishikawa, M. Ishimoto et al. (2019) Nat. Commun. 10: 4033.

Kato, S., Y. Yokota, R. Suzuki, Y. Fujisawa, T. Sayama, A. Kaga, T. Anai, K. Komatsu, N. Oki, A. Kikuchi et al. (2020) Theol. Appl. Genet. 133: 2105-2115.

Krishnamurthy, P., Y. Fujisawa, Y. Takahashi, H. Abe, K. Yamane, K. Mukaiyama, H.-R. Son, S. Hiraga, A. Kaga, T. Anai et al. (2019) Plant Cell Physiol. 60: 1082-1097.

McCallum, C.M., L. Comai, E.A. Greene and S. Henikoff (2000) Nat. Biotech. 18: 455457.

Sarkar, M.A.R., W. Otsu, A. Suzuki, F. Hashimoto, T. Anai and S. Watanabe (2020) Breed. Sci. 70: 265-276.

Sayama, T., T. Tanabata, M. Saruta, T. Yamada, T. Anai, A. Kaga and M. Ishimoto (2017) Breed. Sci. 67: 363-369.

SoyStats (2019) The American Soybean Association. [http://www. soystats.com/].

Takagi, K., R. Yano, S. Tochigi, Y. Fujisawa, H. Tsuchinaga, Y. Takahashi, Y. Takada, A. Kaga, T. Anai, C. Tsukamoto et al. (2018) Phytochem. 156: 96-105.

高木 㭌・S.M. ラーマン (2002) 育種学研究 4: 25-31.

Tsuda, M., A. Kaga, T. Anai, T. Shimizu, T. Sayama, K. Takagi, K. Machita, S. Watanabe, M. Nishimura, N. Yamada et al. (2015) BMC Genom. 16: 1014.

Watanabe, S., R. Hideshima, Z. Xia, Y. Tsubokura, S. Sato, Y. Nakamoto, N. Yamanaka, R. Takahashi, M. Ishimoto, T. Anai et al. (2009) Genetics 182: 1251-1262.

Watanabe, S., Z. Xia, R. Hideshima, Y. Tsubokura, S. Sato, N. Yamanaka, R. Takahashi, T. Anai, S. Tabata, K. Kitamura et al. (2011) Genetics 188: 395-407.

Xia, Z., S. Watanabe, T. Yamada, Y. Tsubokura, H. Nakashima, H. Zhai, T. Anai, S. Sato, T. Yamazaki, S. Lu et al. (2012) Proc. Natl. Acad. Sci. USA 109: E2155-E2164.

Yano, R., K. Takagi, Y. Takada, K. Mukaiyama, C. Tsukamoto, T. Sayama, A. Kaga, T. Anai, S. Sawai, K. Ohyama et al. (2017) Plant J. 89: 527-539.

Yano, R., K. Takagi, S. Tochigi, Y. Fujisawa, Y. Nomura, H. Tsuchinaga, Y. Takahashi, Y. Takada, A. Kaga, T. Anai et al. (2018) Plant Cell Physiol. 59: 797-810. 